\title{
Intelligence as a Main Way to Ensure Universal Sustainability of Country's Development
}

\author{
Aleksandras Vytautas Rutkauskas ${ }^{1}$, Viktorija Stasytyte ${ }^{2},{ }^{1-2}$ Vilnius Gediminas Technical University
}

\begin{abstract}
The paper aims to analyse and propose ways of measuring the synergistic effect that resource allocation to intelligence assets (activities) can have on country's sustainable development and its subsystems. The methodology of adequate portfolio is used in order to determine the optimal structure of resources distributed to each group of intelligence assets planning and data mining, analytical processing and reporting. Applying the proposed methodology and using expert valuations, the synergistic effect on sustainability is measured and expressed in terms of value added/resources saved, their reliability and riskiness. Moreover, this effect impacts all the subsystems in the general scheme of country sustainability, and, in turn, each subsystem can positively influence business value in the particular field of activity.
\end{abstract}

Keywords: adequate portfolio, business intelligence assets (activities), country development sustainability, resource allocation, synergistic effect.

\section{INTRODUCTION}

In a constantly changing multinational environment, the development of a country or a region needs to be sustainable. Thus, there is a need to provide some essential conditions to ensure the sustainable development of each country or region. Along with distinguishing country's (regional) sustainability subsystems, there is a need to stress an important characteristic of all the subsystems -intelligence or, in other words, the adequate and sound use of resources assigned to each subsystem.

Intelligence itself can be analysed in terms of its factors or constituting activities, which can serve as assets to distribute resources in order to reach the desired development sustainability of a country or a region. The optimal allocation of resources can drive their synergistic effect and result not only in positive changes of country's sustainability, but also in an increased business value.

The objective of the research is to propose the solution to optimal allocation of resources among intelligence assets (activities) in order to foster the sustainable development of a country. In order to reach the objective, the methodology of adequate portfolio, based on stochastic optimization, is used.

\section{The NeCESSITy OF COUNTRY’s Sustainable DEVELOPMENT}

\section{A. The Origin and Definition of Sustainability}

Sustainability, as orientation of activity towards satisfying today's needs and leaving for future generations the possibility to satisfy their needs as well, is the main concept of science that is capable of finding the solution to the aforementioned problem [1] - [3]. The concept should match its prototype in each subsystem of sustainability.

Sustainable development retained the knowledge of management and economic science, which has endured the experiments of reality, and revealed the created credo of thought and activity - to sustain ability for that which leads us to the future. The concept of sustainability dominates in the management of scientific cognition and universal knowledge formation.

\section{B. Country's Sustainable Development Analysis and Management Trends}

In this paper, the authors will use their own developed universal concept of sustainability proposed in the 1st World Sustainability Forum [4], subsequent publication in Sustainability journal [5] and in the 7th International Scientific Conference "Business and Management - 2012" [6], which intends to investigate the sustainable development. Fig. 1 presents a slightly modified scheme, disclosing the content of the mentioned concept.

According to Fig. 1, the cognition of universal sustainability is oriented towards the self-sufficient combination of functional components or subsystems.

Four of the subsystems presented in Fig. 1 - the subsystem of ecological sustainability, subsystem of socio-demographic sustainability, subsystem of economic sustainability and subsystem of political sustainability - are practically included into each detailed case of sustainable development. The subsystems of technological and creative sustainability are quite rarely analysed as subsystems of independent development.

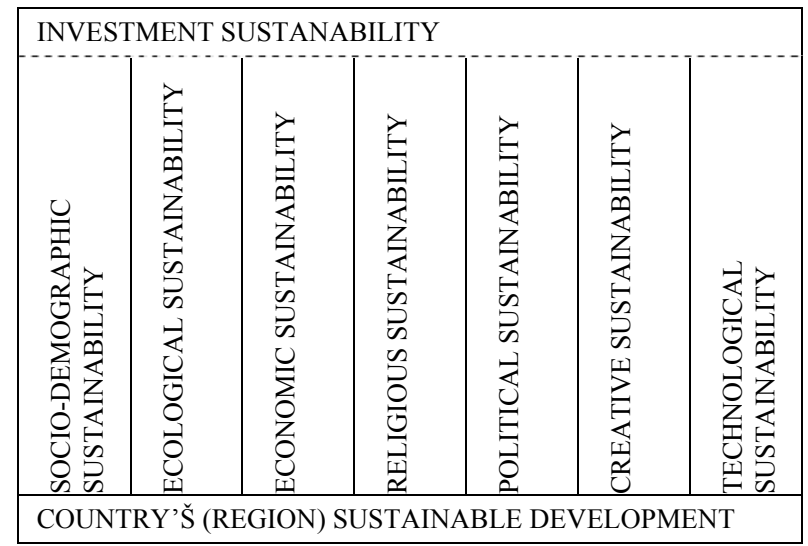

Fig. 1. The scheme of the analysis of country's (region) sustainable development 
$2013 / 24$

The subsystem of religious sustainability has not found its official recognition for quite a long period of time, but it is also an important component of sustainable development.

A subsystem of investment sustainability, which is actually very rarely mentioned, requires a distinct presentation and broad discussion. It assumes an exceptional function - to mobilize resources necessary to maintain the main functions of the aforementioned subsystems and to strengthen their interaction. To a great extent, it covers the resource allocation, and it will be analysed further in the paper.

\section{Universal Sustainability as a Resultant of the Activity of All Sustainability Subsystems}

Speaking about the problems of evaluation and management of sustainability, usually a set of sustainabilities or a structure of universal (from Latin universalis) sustainability is chosen, revealing the opportunities to formulate and solve the specific sustainability problems. As already mentioned, usually the subsystems of social, economic, ecological and political sustainability are distinguished, often - technological and religious sustainability subsystems and rarely - investment sustainability subsystems.

In their previous research [6], the authors explicitly defined each subsystem of universal sustainability related to country's development. Thus, in the present paper such a description is omitted. However, it is worth noticing that losing the strength of sustainability in any universal sustainability subsystem leads to the catastrophic losses for a country or a region, but the possibility or even implementation is not the full source of information on how the strength of sustainability should be fostered.

In order to use the relevant methodology to formulate the decisions of system analysis and management, it is necessary:

- to understand the essence, nature and anatomy of sustainability concept;

- to be able to quantitatively measure the strength of sustainability;

- to be able to relate the positive changes in the strength of sustainability with the required resource volume and structure;

- to be able to understand the link of the strength of universal sustainability with the strength of sustainability subsystems and the possibilities of interaction of these subsystems;

- to be able to disclose the optimal resource allocation among separate subsystems in order to reach the maximum synergistic effect.

It is quite a risky activity to analyse these issues, because literature draws a lot of attention to them and the number of unanswered or even unanswerable questions is not decreasing. However, in order to understand the aforementioned issues, first of all, it is necessary to discuss them.

The main objective of each universal sustainability subsystem, in simple terms, can be understood as a subsystem's ability to maintain, with a high level of guarantee, the certain level of core system parameters above the critical threshold, while dropping below the threshold the subsystem starts losing its ability to rebuild itself as a system. However, undoubtedly the main question arises - what kind of ability the universal sustainability should foster, i.e., the resultant of all sustainability subsystems. Searching for the answer to this question, unambiguously the idea appears that this feature conceptually should be understood as preservation of the ability of subsystems to interact. Actually, the necessity of such feature is proven by analysing the environmental sustainability individually, as well as other sustainability subsystems. However, for individual subsystems the interaction of their elements or subsystems is conceptually more perceivable and unfolding for management. In the case of universal sustainability, there is a need for formation of the perfect concept of interaction, as well as for preparation of engineering foundations of interaction.

The key tasks here are to understand the content, methods and consequences of the universal sustainability and to be able to adequately simulate these processes in order to propose the assumptions for the specialists of various subsystems to discuss on the basis of quantitative information.

\section{ADDRESSING BUSINESS INTELLIGENCE IN Sustainable DEVElopMENT MANAGEMENT}

\section{A. The Need for Business Intelligence}

Taking into account the scheme of the analysis of country's (region) sustainable development presented above, it is worth noticing that in order for all sustainability subsystems to function properly there is a need for their wise management. This can be reached with the help of intelligence qualities possessed by the users and creators of each subsystem and developed by the processes taking place in the subsystem.

\section{B. A Short Discussion about Business Intelligence Assets}

Business intelligence can be properly analysed by distinguishing its assets. Speaking about business intelligence assets, we can note that business intelligence is a means for adding value in production or service delivering process. Commonly it is accepted that business intelligence activity can be applied to the following business purposes in order to drive business value: measurement, analytics, reporting/enterprise reporting, collaboration/collaboration platform, knowledge management [7].

Do business intelligence assets exist? To find an answer to this question, the definition of the word "asset" should be understood. It is a resource with an economic value that an individual, corporation or country owns or controls with the expectation that it will provide future benefit. For a marketer, an asset is a tool or a platform, something you can use over and over without using it up. In fact, the more you invest, the better it gets.

As already mentioned, nowadays there is an opportunity to drive business value also through the business intelligence activities, so the authors of the paper assert that business intelligence activities are the means, which help provide and generate benefits and can be treated as assets in the construction of portfolio of business intelligence assets. 
Business intelligence assets can be accepted as the elementary business intelligence activities.

\section{Distinguishing Business Intelligence Activities}

It is not easy to define the main business intelligence activities. Some scientists divide them into reporting activities, analytical process, statistical analysis, forecasting, and data mining. Others point out five key business intelligence activities: planning, measuring, analysis, communication, and action [8].

A typical business intelligence solution includes data sources, where transactional data is accumulated, data warehouses/data marts, reporting and visualization tools, as well as predictive analytics and modelling [9].

The business intelligence cycle defines the basic steps of the business intelligence process, and consists of four phases [10]:

- Planning and direction: in this phase, the business intelligence cycle is structured;

- Collection of data: in this phase, the necessary data sources are identified and data is collected. After that the collected data can be converted, edited, aggregated, and stored in a structured way;

- Analysis of data: in this phase, the data is used to produce information, by providing context to the collected data, or by discovering patterns and connections in the data;

- Distribution of information: in this phase, the produced information is forwarded to the right people in an appropriate format.

After a short review of business intelligence activities, the conclusion should be made that all existing and different business intelligence activities can be sorted into three main groups: 1) planning and data mining, 2) analytical processing and 3) reporting. Such a division into categories will be further used in this paper to analyse the practical case of resource allocation; however, it is quite a generalized distribution and it is not ultimate. Under other circumstances, other assets or groups of assets can be distinguished.

\section{The Proposed Methodology for Resource ALLOCATION}

\section{A. Integral Business Intelligence Need for Optimal Resource Allocation}

Distribution of resources to the business intelligence activities can increase a business value. If these resources are financial, they must become the capital, which could be measured by its efficiency, risk and so far.

To solve a problem, the adequate portfolio ideology will be used [11] - [13]. As we see the concept of portfolio is very diverse, but almost in all cases there is an opportunity to find out the way to connect the potency of separate assets in a system, not only for the highest result to obtain, but also for the most effective usage of resources. It is a major economic problem and progressive development motto. The idea of portfolio solution method formed by H. Markowitz in 1952 [14] serves as a stochastic optimization technique. Based on this technique, a stochastic optimization problem can be solved. It is interesting to mention that the idea of portfolio and search method of optimal portfolio can be successfully used in nonlinear stochastic optimization.

The effect of each business intelligence asset (activity) is, in fact, a random variable, the particular value of which is not known. The effect can be different in various situations. However, after analysing a large number of hypothetical situations, a trend of effect values can be established, constituting a probability distribution of business intelligence portfolio effects. In order to reveal the dependences and consistent patterns of the mentioned probability distributions, the procedures described in the next subsection should be performed [15].

\section{B. The Use of Adequate Portfolio for the Optimal Allocation of Business Intelligence Resources}

The process of adequate portfolio formation for optimal resource allocation will be described and visualized on the basis of hypothetical portfolio of three assets. The process under analysis should have the following steps:

1) The initial step - it is the search for Markowitz portfolio [14], consisting of possible profitability values' set of the kcomponents of portfolio, measured by possibilities' mean and standard deviation.

2) In order to reflect not only the mean but also all the possibilities, not only the information provided by the "standard deviation - mean" portfolio values is used, but all the "standard deviation - quintiles (percentiles)" (Fig. 2, section a) and the set of its efficient frontiers (Fig. 2, section b)are analysed.

3) In order to obtain evidence on how information is reorganized, conforming to the canons of the formed Markowitz random field (Fig. 3, section a) [16], ( $\sigma, p)$ plane (Fig. 2, section $b$ ) will be shifted to a horizontal position and will be rotated at a $180^{\circ}$, along with that the third coordinate $r$ (reliability) - is included. The final result of these transformations is expressed in the so-called efficient surface (Fig. 3, section a) [11] named after the Markowitz efficient frontier [14].

Fig. 3 illustrates how a change (growth) in portfolio standard deviation affects the business intelligence assets or leadership portfolio effect distribution of possibilities, which in this particular case is a member of the corresponding family of random variables.

Speaking about the formed structure as a random field, we have to remember that for each $\sigma$ value corresponding to the survival function, there is a random variable, and practically every utility function is $\sigma$-measurable function.

Efficient surface is the source of exceptionally important and universal information on possibilities of investment decisions.

Fig. 3, section b illustrates how to select the optimal (according to utility function) solution. The unique solution is found, because the efficient surface and utility surface are convex regarding each other [15]. 
2013/24

\section{profitability}

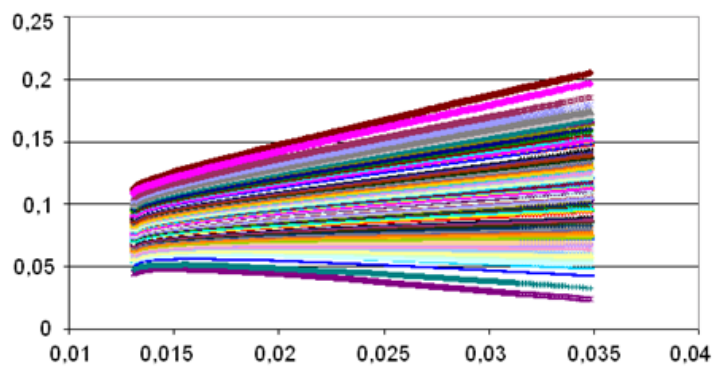

profitability

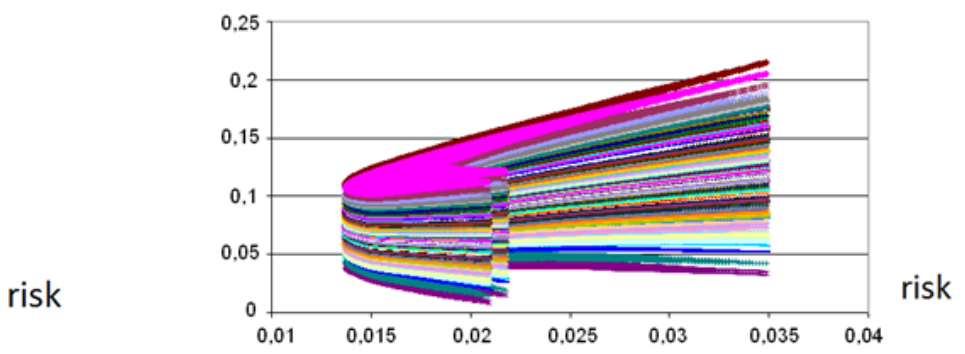

Fig. 2. Markowitz portfolio of three assets, (a) "Standard deviation - percentiles" sets of profitability possibilities, (b) The set of efficient frontiers [15].
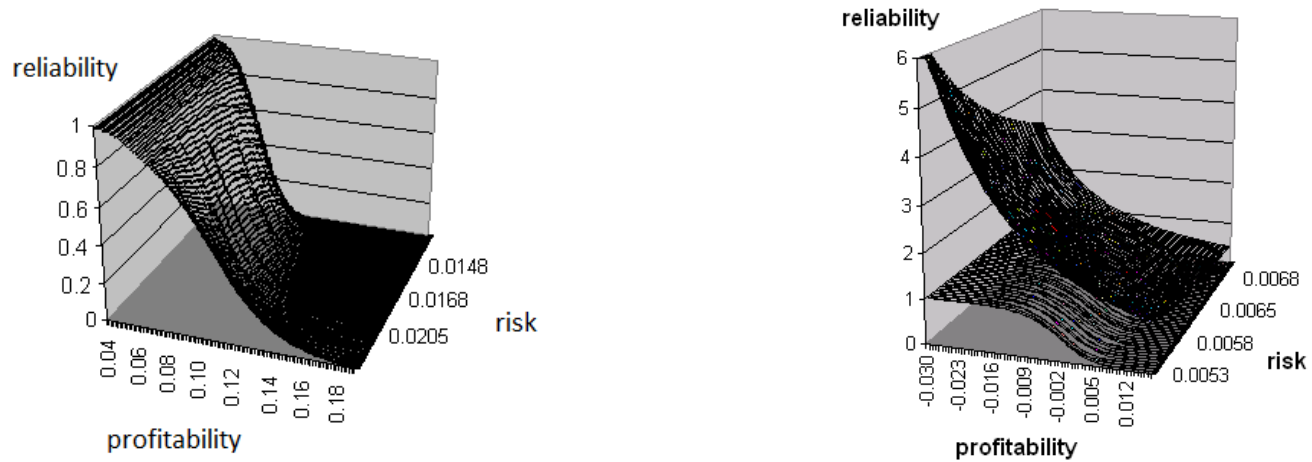

Fig 3. (a) Efficient surface, (b) The best possibility choice [15].

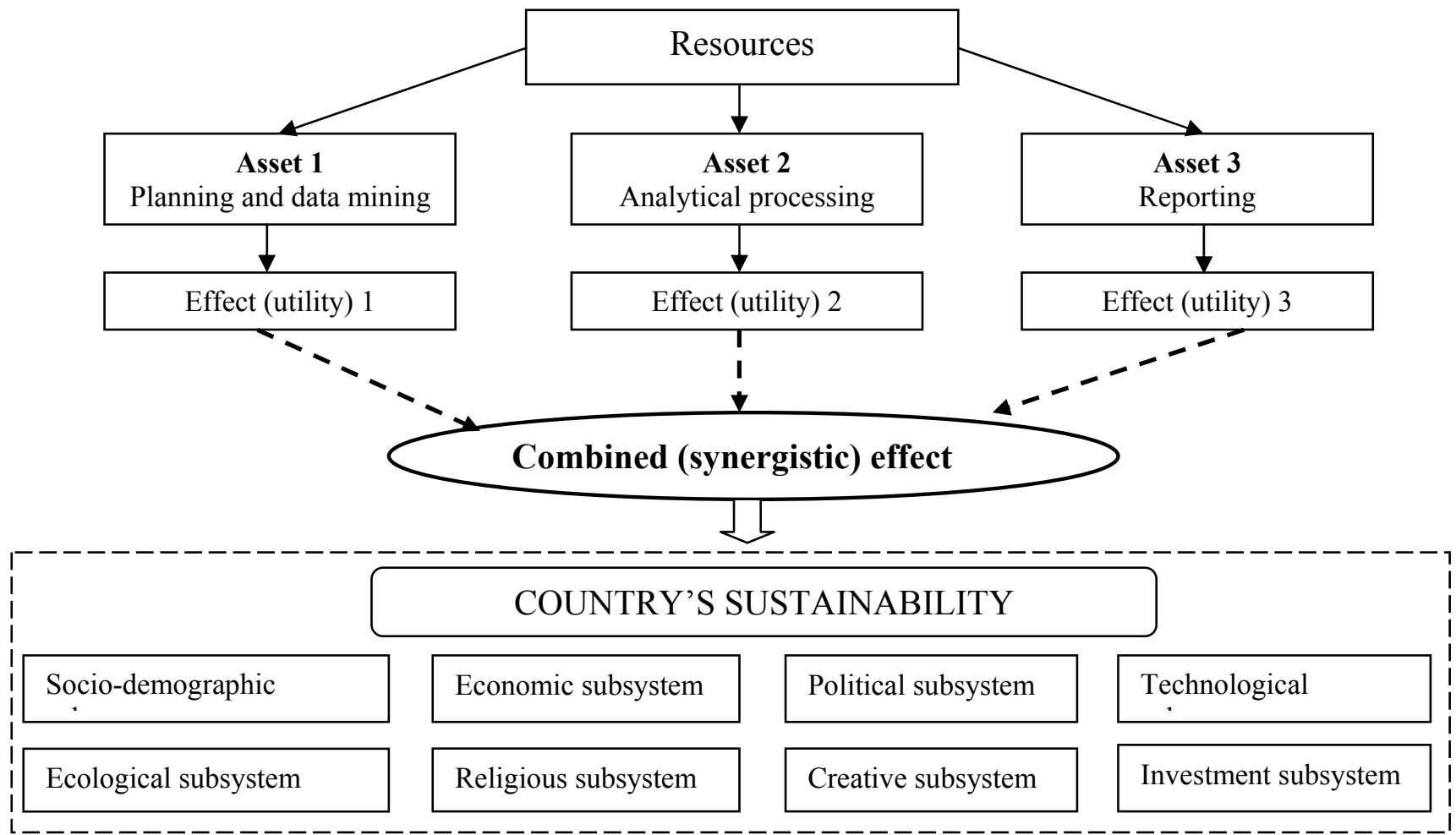

Fig 4. The scheme of formation and spread of resource allocation effect . 
Applying a certain forecasting system and choosing the best option, the overall greatest effect of intelligent asset portfolio can be attained.

\section{InTELligent Resource Allocation to Drive BusINESS VALUE AND COUNTRY’s SUSTAINABILITY}

\section{A. The General Scheme of Resource Allocation}

As already mentioned in Section 3 of the paper, the business intelligence assets can be divided into three main groups:

1) planning and data mining;

2) analytical processing;

3) reporting.

The intended resources are distributed to each group of assets according the adequate portfolio methodology. The expected effect (utility) of each group of assets is expressed in terms of probability distribution, the parameters of which are determined by the experts. The detailed quantitative implementation of the stated problem will be described in the next section of the paper.

The general scheme of resource allocation and their effect, as well as impact on country's sustainability is presented in Fig. 4. While resources are allocated to each group of assets (intelligence activities), they stimulate the increased efficiency in the field of activity related to these groups:

- In planning and data mining group of assets, the additional resources can encourage the efficient use of human, financial and other resources related to planning and data collection; moreover, it can promote the formation of broad statistical databases, useful for business and public sector use;

- To analytical processing group of assets, the allocated resources bring adequate use of historical statistics in order to forecast and model future trends of development (this can be applied to any field of development) and encourage the use of modern social, economic and other research results for the purposes mentioned above;

- In reporting it is important that the right information is provided to the right people at the right time. Adequate reporting of information has a great impact on the efficiency of decisions taken at all levels in various fields of country's development.

With the help of resources assigned, the three mentioned groups of assets should improve their performance in respective areas, as well as have a combined positive effect a synergistic effect - on the general development of country's sustainability, which definitely is higher than just the sum of three separate effects. Moreover, with synergistic effect many different fields of activity (not only these assigned to the 3 groups of assets) will achieve the effect of increased efficiency. That is why on the scheme (Fig. 4) it is possible to observe that the synergistic effect impacts all the subsystems of universal country's sustainable development.

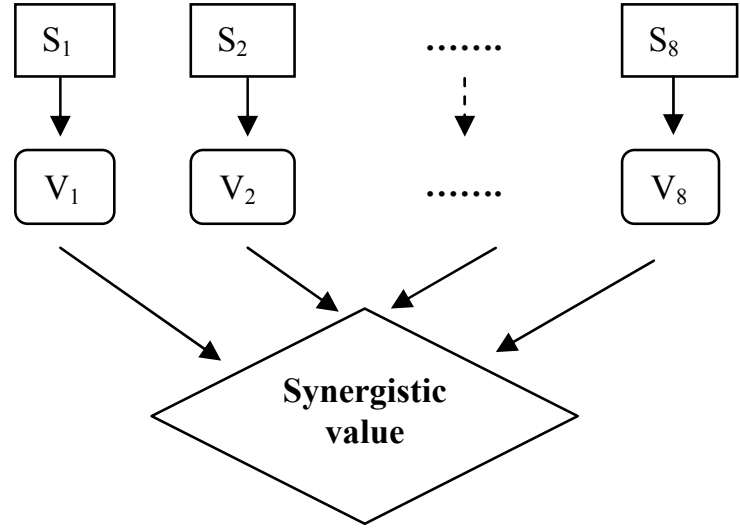

Fig. 5. Formation of synergistic value for business.

The way how the effect influencing the country's sustainable development is distributed to each sustainability subsystem, and how the value added formed in these subsystems creates the value for business is presented in Fig. 5.

Each sustainability subsystem out of 8 is assigned a designation from $S_{1}$ to $S_{8}$, and the value it produces for business is denoted as $V_{1}$ to $V_{8}$. The particular description of the value corresponding to each subsystem is beyond the scope of this article and is subject for further research.

The combination of the separate values results in $a$ synergistic value for business. Hypothetically, it can be perceived as the general value for the business sector in a particular country. However, more often it can be seen as the value for a particular company, group of companies or a business sector.

\section{B. Characteristics of Intelligence Asset Effect Measurement}

Let us suppose that in the operation of a company or any other entity there is a certain fund, which can be distributed among the intelligence activities (or group of assets), thus reaching the desired effects and contributing to the synergistic effect. The effect (E) of each group of assets can be expressed as a stochastic variable - probability distribution (D) with its parameters - mean value $(\mathrm{m})$ and standard deviation (s), which are determined by the experts:

$$
\mathrm{E}=\mathrm{D}(\mathrm{m}, \mathrm{s})
$$

The expert valuations are the following:

$\mathrm{D}(1.2 ; 0.2)$ - for planning and data mining group of assets;

$\mathrm{D}(1.0 ; 0.25)$ - for analytical processing group of assets;

$\mathrm{D}(0.95 ; 0.15)$ - for reporting group of assets.

The possibilities of synergistic effect are characterized by the extent of value added or resources saved as a result of this effect, as well as by the reliability of the value/resources and by riskiness. It is obvious that it is necessary to know the way how to select the possibility (the percentage structure according to which the initial resources are allocated among the intelligence activities) that guarantees the maximum value added or resources saved. Such a possibility, expressed in 
terms of the extent, guarantee and riskiness, should have the highest possible utility under the particular predetermined utility function form. The utility function analogue is the following [6]:

$$
U=u(e, p, r)=\frac{e p_{e}}{r_{e}}
$$

where:

e - the extent of value possibility;

$\mathrm{p}$ - the guarantee of the value possibility;

$\mathrm{r}$ - riskiness of value possibility set.

Using the above formula, it is possible to fully describe and compare various opportunities of resource allocation and their effects, and to select the optimal solution.

\section{Graphical Case Analysis}

Using the expert valuations presented in the previous subsection, as well as adequate portfolio methodology described in section IV, subsection B, the author of the paper will practically analyse the resource allocation attaining the synergistic effect.

The possibilities (the quartiles) of value added/resources saved on a two-dimensional plane are presented in Fig. 6, the three-dimensional efficient surface (value possibilities, reliability and riskiness) - in Fig. 7, and a two-dimensional layer showing an intersection point of possibility set (survival function) with utility function - in Fig. 8.

The parameters of the optimal solution (the intersection point) are the following:

$$
\begin{aligned}
& \mathrm{e}-1.07 \\
& \mathrm{p}-0.49 \\
& \mathrm{r}-0.12
\end{aligned}
$$

In terms of resource allocation, the following parts of the number of resources, intended for distribution among intelligence assets, should be allocated in such a way:

- for planning and data mining group of assets -0.285 ;

- for analytical processing group of assets -0.325 ;

- for reporting group of assets -0.39 .

As a result, it is possible to observe that resources should be allocated among the three groups of intelligence assets more or less equally, with the highest preference given to the reporting group, which seems interesting enough.

Furthermore, it is worth noticing that the proposed structure of allocation of resources is designed for a generalized form of utility function, as well as for the assumed three-asset portfolio. In practice, such a portfolio of intelligence assets can have more assets or asset groups, and, in turn, it will impact the resource allocation structure. Moreover, in a particular situation, depending on the business sector and objectives of resource fund owner, the utility function can have a different form, thus, influencing the capital allocation structure. Technically, such a solution is made by adding the determined coefficients to the formula of utility. Conceptually, it implements the perception that a certain group of assets can have a stronger impact on achieving some corporate objectives.

value possibilities

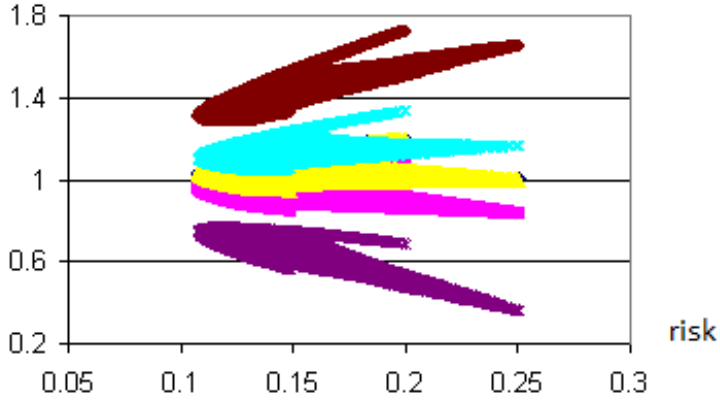

Fig. 6. "Standard deviation - quartiles" sets of value added/resources saved possibilities.

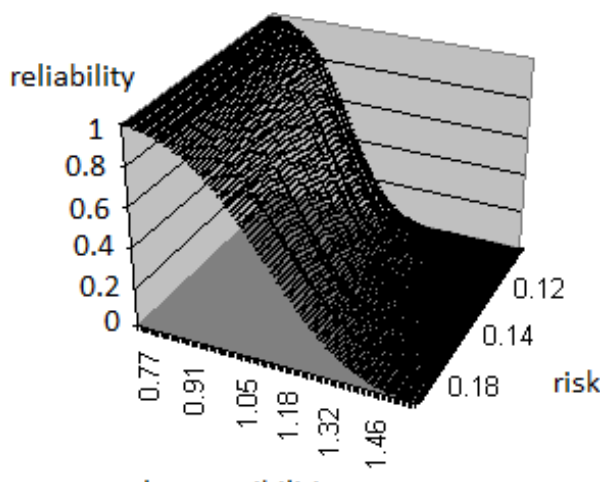

value possibilities

Fig. 7. The efficient surface.

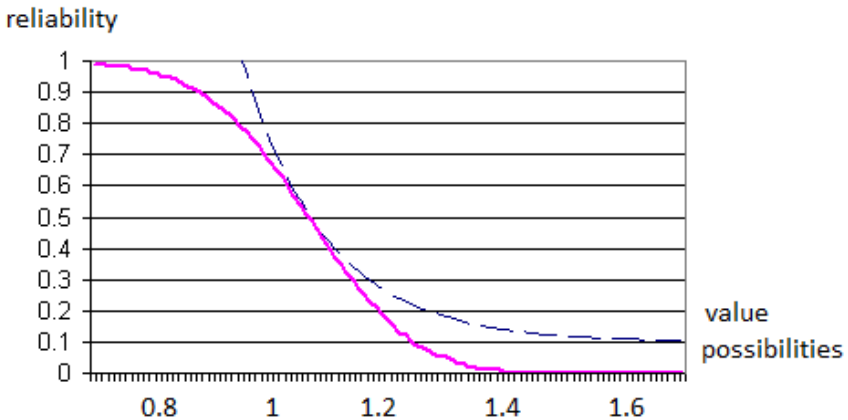

Fig. 8. Finding the intersection point.

\section{CONCLUSION}

The concept of sustainability, which brings the credo "to sustain ability for that which leads us to the future", fosters the formation of scientific knowledge field, called the sustainable development. 
The scheme of the analysis of country's (region) sustainable development invokes the following subsystems: sociodemographic, economic, ecological, political, technological, religious, creative and investment sustainability. Losing the strength of sustainability in any universal sustainability subsystem leads to the catastrophic losses for a country or a region, and, on the other hand, the efficient operation of which allows retaining and improving general sustainability power.

Allocating resources to three main groups of intelligence assets (activities) - planning and data mining, analytical processing and reporting allows achieving the synergistic effect for country's sustainable development, the positive impact of which is further distributed to sustainability subsystems. In turn, each subsystem of universal country sustainability produces a certain value added for business, which results in a synergistic value.

Applying the relevant portfolio methodology and using expert valuations, it is possible to find the optimal structure of resource allocation to the groups of intelligence assets and also to measure the synergistic effect on sustainability in terms of value added/resources saved, their reliability and riskiness.

\section{REFERENCES}

[1] W. C. Clark and N. M. Dickson,“ Sustainability science: The emerging research program", in Proceedings of the National Academy of Sciences, Vol. 100, No 14, USA, 2003, pp. 8059-8061.

[2] W. R. Blackburn, The Sustainability Handbook. Earthscan, London, UK. 2007.

[3] Ph. Sinclair, "Describing the elephant: A framework for supporting sustainable development processes", Renewable and Sustainable Energy Reviews, Vol. 15, No. 6, 2011, pp. 2990-2998. http://dx.doi.org/10.1016/j.rser.2011.03.012

[4] A. V. Rutkauskas, V. Stasytytė and I. Lapinskaite, "Sustainabilities Portfolio as System to Envisage and Manage Universal Sustainability", in Proceedings of the 1st World Sustainability Forum, E-Conference, , 1 30 November 2011.

[5] A. V. Rutkauskas, „Using Sustainability Engineering to Gain Universal Sustainability Efficiency“, Sustainability, Vol. 4, No 6, 2012, pp. 1135 1153. http://dx.doi.org/10.3390/su4061135

[6] A. V. Rutkauskas and V. Stasytytè, „With sustainability engineering to sustainability efficiency“, in The $7^{\text {th }}$ International Scientific Conference "Business and Management 2012": selected papers, Vol. 1, May 10-11, 2012. Vilnius: Technika, 2012, pp. 173-184.

[7] A. V. Rutkauskas, I. Lapnskaite and V. Stasytyte, "Portfolio of Business Intelligence Assets as Means to Envisage and Manage Integrated Intelligence of Business", in The International Scientific Conference "Whither our Economies”, November 16-17, 2011, Vilnius, Lithuania, pp. 219-226.

[8] „Activities for Business Intelligence Efforts“, [Online]. Available: http://www.illuminationworksllc.com/activitiesfor bi.pdf [Accessed: $20^{\text {th }}$ of June, 2012].

[9] N. Brannon, "Business Intelligence and E-Discovery", Intellectual Property \& Technology Law Journal, Vol. 22, No. 7, July 2010, pp. 1-6.

[10] R. M. Müller, S. Linders and L. F. Pires, „Business Intelligence and Service-oriented Architecture: A Delphi Study“, Information Systems Management, Vol. 27, 2010, pp. 168-187. http://dx.doi.org/10.1080/10580531003685238

[11] A. V. Rutkauskas, "Adequate Investment Portfolio Anatomy and Decisions, Applying Imitative Technologies", Economics, Vol. 75, 2006, pp. 52-76.

[12] A. V. Rutkauskas and V. Stasytyte, ,Optimal portfolio search using efficient surface and three-dimensional utility function", Technological and Economic Development of Economy. Vilnius: Technika, Vol. 17, No. 2, 2011, pp. 291-312.

[13] A. V. Rutkauskas, V. Stasytytè and J. Borisova, "Adequate portfolio as a conceptual model of investment profitability, risk and reliability adjustment to investor"s interests“, Economics and Management.
Kaunas: Kaunas University of Technology Press, No. 14, 2009, pp. 1170-1174.

[14] H. M. Markowitz, „Portfolio Selection“, Journal of Finance, Vol. 7, No. 1, 1952, pp. 77-91. http://dx.doi.org/10.1111/j.15406261.1952.tb01525.x. http://dx.doi.org/10.2307/2975974

[15] A. V. Rutkauskas and V. Stasytytè, "Leadership intelligence: how to get there?", Procedia - Social and Behavioral Sciences, 2012 (to be published).

[16] A. V. Rutkauskas and V. Stasytyte, "Markowitz Random Field as a Stand for Investment Analysis and Decision Making", in The 15th World Multi-Conference on Systemics, Cybernetics and Informatics: WMSCI 2011, July 19th - July 22nd, 2011, Orlando, Florida, USA, pp. 131-136.

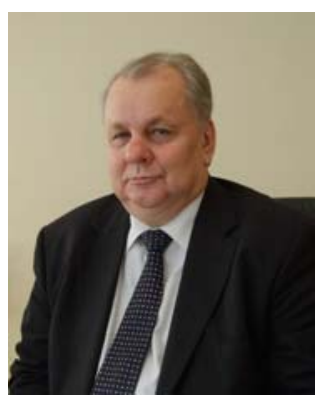

A. V. Rutkauskas has a Diploma in Mathematics (probability theory) (1964), a Doctoral Degree in Economics (1974), a Habilitated Doctoral dDgree (1990). He became a Professor in 1993.

In 1976-1993, prof. A. V. Rutkauskas was the Head of the Department of Regional Development at the Institute of Economics of the Lithuanian Academy of Sciences. In 19911993, he was also the Head of the Department of Investment Policy of the Institute of Economics and Privatisation. Since 1993 A. V. Rutkauskas is a Professor at the Department of Economics (which in 2001 changed its name to the Department of Finance, and in 2004 - to the Department of Finance Engineering) of Vilnius Gediminas Technical University (VGTU). In 2002-2011, he was the Dean of the Faculty of Business Management, VGTU. In 1993-2006, and since 2011 the Head of the Department of Finance Engineering, VGTU.

The most important scientific publications of A. V. Rutkauskas are as follows:

[1] A. V. Rutkauskas, "On the sustainability of regional competitiveness development considering risk", Technological and Economic Development of Economy: Baltic Journal on Sustainability. Vilnius: Technika. Vol. 14, No. 1, 2008, pp. 89-99.

[2] A. V. Rutkauskas, Profit Engineering. Vilnius: UAB Ciklonas, 2007. $196 \mathrm{p}$.

[3] A. V. Rutkauskas and R. Martinkutè, Investment Portfolio Anatomy and Management. Monograph. Vilnius: Technika, 2007, 360 p.

The areas of research interest of prof. A. V. Rutkauskas used to be finance, environmental economics, regional development, risk management, quantitative models of social processes. At present, he is interested in investment portfolio management in capital and exchange markets; risk and uncertainty; sustainable development; integrated value and risk management.

A. V. Rutkauskas is a member of the International Association for Energy

Economics (IEEA), European Regional Science Association (ERSA), Lithuanian Programme of Man and Biosphere (LPMB), International Institute of Informatics and Systemics (IIIS). He received the Best Paper Award in the Session "Sustainability in Financial Markets Behaviour: Concept, Problems, Decisions" of the 12th World Multi-Conference on Systemics, Cybernetics and Informatics, 2008, Orlando, Florida for the paper "Prospecting for Sustainable Investment Possibilities in Financial Markets" (paper authors: V. Stasytytė and A. V. Rutkauskas).

Address: Sauletekio ave. 11, SRC-605, LT-10223, Vilnius, Lithuania.

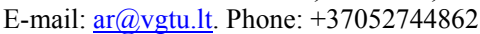

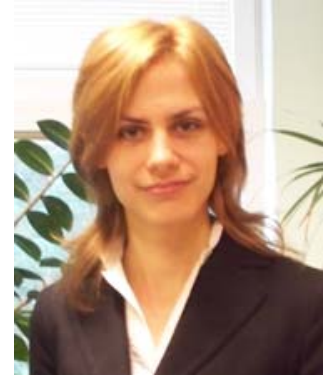

V. Stasytytè has a Master Degree in Management and Business Administration (2007), Doctoral Degree in Economics (2011).

In 2005-2011, V. Stasytytė worked as a Senior Manager at the Department of Finance Engineering of Vilnius Gediminas Technical University (VGTU). In 2011 she became an Assistant at the Department of Finance Engineering, VGTU. In 2011-2012, she was a Researcher at JSC "Prosperitus", and since 2011 - an Associate Professor at the Department of Finance Engineering, VGTU.

The most important scientific publications of V. Stasytyte are as follows: 
[1] A. V. Rutkauskas and V. Stasytyte, "Markowitz random field as a stand for investment analysis and decision making", in the 15th World MultiConference on Systemics, Cybernetics and Informatics: WMSCI 2011. July 19 - July 22, 2011 Orlando, Florida, USA: proceedings. Vol. 1 Orlando: International Institute of Informatics and Systemics, 2011, pp. 131-136.

[2] A. V. Rutkauskas, A. Miečinskienè and V. Stasytyte, "Investment decisions modelling along sustainable development concept on financial markets", Technological and Economic Development of Economy: Baltic Journal on Sustainability. Vilnius: Technika. Vol. 14, No. 3, 2008, pp. 417-427.

[3] V. Stasytyte, "From two-dimensional profit-risk to three-dimensional profit-reliability-risk in capital markets", in EURO Mini Conference "Continuous Optimization and Knowledge-Based Technologies" (EurOPT'2008): the 20th International Conference. May 20-23, 2008,

Neringa, Lithuania: selected papers. Vilnius: Technika, 2008. pp. 149153.

The areas of research interest of V. Stasytyte are capital markets; investment portfolio management, risk management; sustainable development.

V. Stasytyte received the award for the best master thesis related to country economic growth and increase of competitiveness $\left(2^{\text {nd }}\right.$ place $)$ from the Ministry of Economy of the Republic of Lithuania in 2007. Also, she received the Best Paper Award in the Session "Sustainability in Financial Markets Behaviour: Concept, Problems, Decisions" of the 12th World MultiConference on Systemics, Cybernetics and Informatics, 2008, Orlando, Florida for the paper "Prospecting for Sustainable Investment Possibilities in Financial Markets" (paper authors: V. Stasytytė and A. V. Rutkauskas).

Address: Sauletekio ave. 11, SRC-605, LT-10223, Vilnius, Lithuania. E-mail: viktorija.stasytyte@vgtu.lt. Phone: +37052744862.

Aleksandras Vitautas Rutkauskis, Viktorija Stasutute. Intelektuālais kapitāls kā universāls valsts ilgtspējīgas attīstības nodrošināšanas veids

Raksta mērķis ir analizēt un piedāvāt veidus, kā mērīt sinerǵiskos efektus, kuri var atstāt iespaidu uz valsts ilgtspējīgu att̄̄istību un tās apakšsistēmām, piešķirot resursus intelektuālajiem aktīviem (aktivitātēm). Autori izmanto portfolio metodologiju, lai noteiktu optimālo resursu struktūru katrai intelektuālo aktīvu grupai (plānošanai un datu apstrādei, analizēšanai un pārskatu sniegšanai). Pielietojot piedāvāto metodologiiju un izmantojot ekspertu vērtējumus, sinerğiskie efekti uz ilgtspēju tiek mērīti un izteikti kā pievienotā vērtība, ietaupītie resursi, to uzticamība un risks. Turklāt šie efekti ietekmē visas valsts ilgtspējas apakšsistēmas, kuras pēc tam var pozitīvi ietekmēt biznesu vērtību.

\footnotetext{
Александрас Вутаутас Руткаускас, Виктория Стасутуте. Интеллектуальный капитал как главный способ обеспечения универсального долгосрочного развития страны

Цель статьи- анализировать и предлагать способы измерения синергистических эффектов, которые могут проявляться на долгосрочное развитие страны при предоставлении ресурсов интеллектуальным активам (действиям). Авторы используют соответствующую методологию „рогtfolio”, чтобы определить оптимальную структуру ресурсов, распределенных каждой группе интеллектуальных активов - планирование и сбор данных, аналитическая обработка и сообщение. Применяя предложенную методологию и используя экспертную оценку, синергистический эффект на долгосрочное развитие измеряется и выражается как добавленная стоимость, сэкономленные ресурсы, их надёжность и рискованность. Кроме того, этот эффект воздействует на все подсистемы в общей схеме долгосрочного развития страны, и, в свою очередь, каждая подсистема может положительно влиять на деловую ценность в конкретной области деятельности.
} 